\title{
Pengaruh Minyak Zaitun dan Olahraga Intensitas Sedang Terhadap Kadar LDL pada Tikus (Rattus novergicus $L$ ) Galur Wistar yang Diberi Diet Tinggi Lemak
}

\author{
Rahmi Fadhilah ${ }^{1 *}$, Hendra Sutysna ${ }^{2}$ \\ 1) Program Studi Kedokteran, Fakultas Kedokteran Universitas Muhammadiyah Sumatera Utara \\ 2) Departemen Anatomi, Fakultas Kedokteran Universitas Muhammadiyah Sumatera Utara \\ *chacafadhilah26@gmail.com
}

\begin{abstract}
Background: Dyslipidemia is a disorder in lipid metabolism. In addition to synthetic drugs, there are olive oil plants to reduce cholesterol levels that contain MUFA and polyphenols. Purposes: To determine the effect of olive oil and moderate intensity exercise on LDL levels in male Wistar rats (Rattus novergicus L) fed a high-fat diet. Method: True experimental, pretest and post-test design with Control Group. The study was divided into 4 groups, namely positive control $(K)$ given egg yolk $5 \mathrm{mg} / 200$ grams BB / day. $P(1)$ was given 0.9 grams of olive oil every day. $P(2)$ is given exercise for 1 minute 10 seconds. $P(3)$ were given olive oil and moderate exercise intensity and compared LDL levels in each group. Results: The average LDL in the positive control group was pre-test $14 \mathrm{mg} / \mathrm{dl}$, post-test $10.66 \mathrm{mg} / \mathrm{dl}$. P (1) pretest $10.66 \mathrm{mg} / \mathrm{dl}$, post-test $7.66 \mathrm{mg} / \mathrm{dl}$. P (2) pre-test $16.16 \mathrm{mg} / \mathrm{dl}$, post-test $8 \mathrm{mg} / \mathrm{dl} . P(3)$ pre-test $19.16 \mathrm{mg} / \mathrm{dl}$ and post-test $5.33 \mathrm{mg} / \mathrm{dl}$. Conclusion: Exercise and combination of olive oil with moderate intensity exercise have an effect on decreasing blood LDL levels in male Wistar rats (Rattus novergicus $L$ ) who are given a high-fat diet.
\end{abstract}

Keywords: Dyslipidemia, LDL, Olive oil, Sports.

\begin{abstract}
ABSTRAK
Latar Belakang: Dislipidemia adalah kelainan pada metabolisme lipid. Selain obat sintetis, terdapat tanaman Minyak zaitun untuk menurunkan kadar kolesterol yang mengandung MUFA dan Polifenol. Tujuan: Mengetahui pengaruh minyak zaitun dan olahraga intensitas sedang terhadap kadar LDL pada tikus jantan galur wistar (Rattus novergicus $L$ ) yang diberi diet tinggi lemak. Metode: Eksperimental, rancangan pre-test dan post-test dengan kelompok kontrol. Penelitian dibagi 4 kelompok, yaitu Kontrol positif (K) diberi kuning telur 5mg/200 gram $\mathrm{BB} /$ hari. $\mathrm{P}(1)$ diberi minyak zaitun 0,9 gram setiap hari. $\mathrm{P}(2)$ diberi olahraga selama 1 menit 10 detik. $\mathrm{P}(3)$ diberi minyak zaitun dan olahraga intensitas sedang dan dibandingkan kadar LDL tiap kelompok. Hasil: Rata-rata LDL pada kelompok kontrol positif pre-test $14 \mathrm{mg} / \mathrm{dl}$, post-test $10,66 \mathrm{mg} / \mathrm{dl}$. $\mathrm{P}(1)$ pre-test $10,66 \mathrm{mg} / \mathrm{dl}$, post-test $7,66 \mathrm{mg} / \mathrm{dl} . \mathrm{P}(2)$ pre-test $16,16 \mathrm{mg} / \mathrm{dl}$, post-test $8 \mathrm{mg} / \mathrm{dl} . \mathrm{P}(3)$ pre-test $19,16 \mathrm{mg} / \mathrm{dl}$ dan post-test $5,33 \mathrm{mg} / \mathrm{dl}$. Kesimpulan: Olahraga dan kombinasi minyak zaitun dengan olahraga intensitas sedang berpengaruh dalam penurunan kadar LDL darah tikus jantan galur wistar (Rattus novergicus $L$ ) yang diberi diet tinggi lemak.
\end{abstract}

Kata kunci: Dislipidemia, LDL, Minyak zaitun, Olahraga. 


\section{PENDAHULUAN}

Dislipidemia merupakan salah satu faktor penting yang mencetuskan terjadinya PJK. Dislipidemia adalah suatu kondisi kelainan pada metabolisme lipid yang ditandai dengan peningkatan kolesterol total Plasma (PTC), trigliserida (TG), lipoprotein densitas rendah (LDL) dan penurunan kadar lipoprotein densitas tinggi (HDL) (1).

Pada tahun 2017 data World Health Organization (WHO) menunjukkan bahwa penyakit kardiovaskular menjadi penyebab nomor satu kematian penduduk di dunia. Diperkirakan sekitar 17,7 juta orang meninggal akibat penyakit ini, mewakili 31,1\% kematian di dunia. Kematian akibat Penyakit Jantung Koroner (PJK) 7,4 juta (42,3\%) dan 6,7 juta (38\%) disebabkan oleh stroke (2).

Saat ini di tengah masyarakat marak beredar berbagai jenis obat sintetis untuk menurunkan kadar kolesterol. Selain berbagai jenis obat sintetis, di alam terdapat beberapa tanaman yang memiliki manfaat teraupetik untuk pengembangan fitofarmaka. Minyak zaitun adalah salah satu contoh dari fitofarmaka (3).

Minyak zaitun adalah lemak hasil olahan dari buah zaitun yang memiliki kandungan MUFA (Mono Unsaturated Fatty Acid), yang sebagian besar terdapat dalam bentuk asam oleat (70-80\%). Minyak zaitun ekstra virgin adalah jenis minyak zaitun yang sering dikonsumsi karena berasal dari perasan pertama buah zaitun sehingga masih banyak memiliki kandungan zat gizi seperti 36 jenis polifenol yang memiliki manfaat untuk kesehatan (4). Manfaat Polifenol dari extra virgin olive oil memberikan efek protektif dan sebagai antioksidan yang dapat mengikat LDL teroksidasi. Untuk menurunkan kadar LDL, konsumsi makanan yang mengandung asam oleat sebanyak $15 \%$ dari total kebutuhan energi dalam sehari $(4,5)$.

Semakin banyak aktivitas fisik maka semakin sedikit kemungkinan mengalami obesitas dan aktivitas fisik tersebut juga memegang peranan terhadap distribusi lemak tubuh, yang selanjutnya dapat mengurangi risiko kardiovaskuler (6).

Latihan olahraga aerobik merupakan aktivitas olahraga dengan intensitas rendah hingga sedang yang dilakukan secara terus menerus, seperti: jalan kaki, lari, bersepeda dan jogging sedangkan latihan olahraga anaerobik merupakan aktivitas dengan intensitas tinggi yang membutuhkan energi secara cepat dalam waktu singkat, namun tidak dapat dilakukan secara terus-menerus dengan durasi lama (7).

Dari berbagai latar belakang diatas, maka peneliti ingin mengkaji lebih jauh mengenai pengaruh minyak zaitun (Extra virgine olive oilEVOO) dan olahraga intensitas sedang yang dihubungkan dengan kadar LDL pada tikus jantan galur wistar (Rattus novergicus $L$ ) yang telah diberi diet tinggi lemak.

\section{METODE}

Penelitian ini merupakan jenis penelitian eksperimental (true experiment design). Adapun rancangan penelitian yang digunakan adalah pre-test dan post-test dengan kelompok kontrol dengan randomisasi sederhana.

Penelitian dilakukan pada bulan September 2019 sampai Februari 2020 di Laboratorium Unit Pemeliharaan Hewan Laboratorium (UPHL) Fakultas Kedokteran Universitas Muhammadiyah Sumatera Utara (UMSU) Jl. Gedung Arca No. 53 Medan. Pemeriksaan kadar LDL dilakukan di Laboratorium Kesehatan Daerah Provinsi Sumatera Utara Jl. William Iskandar pasar V barat II No. 4.

Sampel penelitian adalah minimal 24 ekor tikus jantan galur wistar (Rattus novergicus L) yang dipilih dengan teknik randomisasi (acak) sederhana. Sampel dikelompokkan atas 4 kelompok, yaitu kelompok 1 sebagai kontrol, kelompok II , III dan IV sebagai perlakuan.

Teknik pengumpulan data diperoleh berdasarkan hasil pemeriksaan kadar LDL Tikus jantan galur wistar (Rattus novergicus L) 
yang diperiksa di laboratorium Kesehatan Daerah Provinsi Sumatera Utara.

Data dianalisis menggunakan aplikasi Statistical Product and Service Solutions (SPSS) versi 24 pada komputer. Uji normalitas dilakukan terlebih dahulu. Apabila hasil uji normalitas Saphiro wilk dan homogenitas normal dan tidak menunjukkan perbedaan bermakna maka dilanjutkan dengan uji sampel berpasangan jika nilai $\mathrm{p}>0,05)(8)$.

Penelitian ini telah mendapatkan keterangan lolos kaji etik dari KEPK Fakultas Kedokteran Universitas Muhammadiyah Sumatera Utara dengan nomor 319/KEPK/FKUMSU/2019.

\section{HASIL}

Penelitian ini menggunakan sampel sebanyak 24 ekor tikus jantan galur wistar (Rattus novergicus L.) dan dibagi menjadi empat kelompok, yang masing-masing terdiri dari 6 ekor tikus tiap kelompok kontrol dan perlakuan. Pada penelitian ini tikus jantan galur wistar (Rattus novergicus $L$.) melalui masa aklimatisasi selama satu minggu, dilanjutkan pemberian diet tinggi lemak dengan menggunakan kuning telur selama dua minggu. Pada hari ke-22 dilakukan pemeriksaan LDL pertama. Pada hari ke-23 dilakukan pemberian minyak zaitun selama 15 hari, dilanjutkan pemberian latihan olahraga intensitas sedang yaitu dengan berenang selama 14 hari. Pada hari ke-38 dilakukan pemeriksaan kadar LDL kedua.

Dari pemeriksaan kadar LDL tikus jantan galur wistar (Rattus novergicus L.) diperoleh rata-rata kadar LDL sebagai berikut:

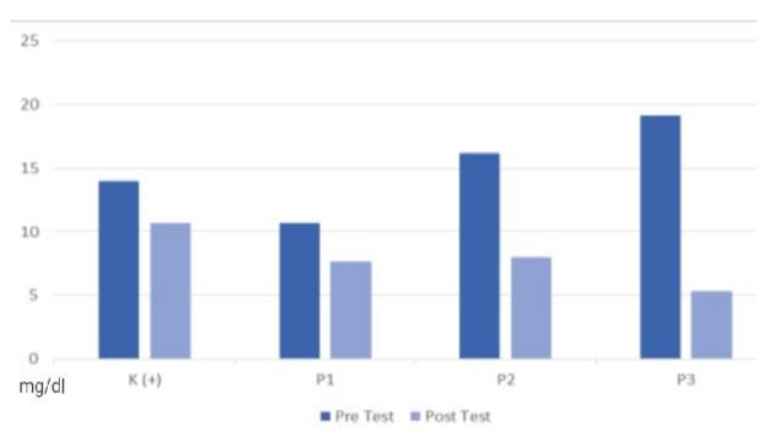

Gambar 1. Rata - rata Kadar Low Density Lipoprotein (LDL)

Keterangan:

Kontrol $=$ Kelompok yang diberi diet tinggi lemak

P1 = Kelompok yang diberi Minyak zaitun (Extra virgine olive oil)

$\mathrm{P} 2$ = Kelompok yang diberi Olahraga Intensitas sedang

P3 = Kelompok yang diberi Minyak zaitun (Extra virgine olive oil) dan Olahraga Intensitas sedang

Dari gambar diatas terlihat adanya perbandingan kadar LDL pada masingmasing kelompok. Kadar LDL kelompok P3 yang diberikan minyak zaitun dan Olahraga intensitas sedang terlihat lebih tinggi dibandingkan dengan kelompok perlakuan yang diberikan minyak zaitun saja atau diberikan olahraga saja.

Tabel 1. Hasil Uji Paired Sample T-Test

\begin{tabular}{cccc}
\hline \multirow{2}{*}{$\begin{array}{c}\text { Kelompok } \\
\text { Uji }\end{array}$} & \begin{tabular}{c}
\multicolumn{2}{c}{ Rata-rata } \\
$(\mathrm{mg} / \mathrm{dl})$
\end{tabular} & $\begin{array}{c}\text { Post- } \\
\text { test } \\
(\mathrm{Mg} / \mathrm{dl})\end{array}$ & \\
\cline { 2 - 3 } & 14 & 10,66 & 0,001 \\
\hline $\mathbf{K}(+)$ & 10,66 & 7,66 & 0,171 \\
\hline $\mathbf{P 1}$ & 16,16 & 8 & 0,026 \\
\hline $\mathbf{P 2}$ & 19,16 & 5,33 & 0,016 \\
\hline
\end{tabular}

Keterangan: $p>0,005=$ signifikan 
Nilai $p$ pada uji normalitas saphiro wilk pada LDL kelompok kontrol pre-test yaitu 0,119 dan LDL kelompok kontrol post-test yaitu 0,318. Maka analisa data selanjutnya menggunakan uji Paired Sample T-Test. Pada uji Paired Sample T-Test diperoleh nilai mean $14,00 \mathrm{mg} / \mathrm{dl}$ pada LDL kelompok kontrol pretest dan 10,71 mg/dl pada LDL kelompok kontrol post-test. Selanjutnya nilai $p$ pada uji Paired Sample T-Test diperoleh sebesar 0,000 $(p<0,05)$. Hal ini menunjukkan ada perbedaan yang signifikan kadar LDL kelompok kontrol pre dan post-test.

Nilai sig. pada uji normalitas saphiro wilk pada LDL kelompok perlakuan 1 (P1) pre-test yaitu 0,166 dan LDL kelompok perlakuan 1 (P1) post-test yaitu 0,387. Maka analisa data selanjutnya menggunakan uji Paired Sample T-Test. Pada uji Paired Sample T-Test diperoleh nilai mean $10,67 \mathrm{mg} / \mathrm{dl}$ pada LDL kelompok perlakuan 1 (P1) pre-test dan 7,67 mg/dl pada LDL kelompok perlakuan 1 (P1) post-test. Selanjutnya nilai sig. Pada uji Paired Sample T-Test diperoleh sebesar 0,171 $(>0,05)$. Hal ini menunjukkan tidak ada perbedaan yang signifikan kadar LDL kelompok kontrol pre dan post-test.

Nilai sig. pada uji normalitas saphiro wilk pada LDL kelompok perlakuan 2 (P2) pre-test yaitu 0,308 dan LDL kelompok perlakuan 2 (P2) post-test yaitu 0,272. Maka analisa data selanjutnya menggunakan uji Paired Sample T-Test. Pada uji Paired Sample T-Test diperoleh nilai mean $13,63 \mathrm{mg} / \mathrm{dl}$ pada LDL kelompok perlakuan 2 (P2) pre-test dan 7,50 mg/dl pada LDL kelompok perlakuan 2 (P2) post-test. Selanjutnya nilai sig. Pada uji Paired Sample T-Test diperoleh sebesar 0,034 $(<0,05)$. Hal ini menunjukkan ada perbedaan yang signifikan kadar LDL kelompok kontrol pre dan post-test.

Nilai sig. Pada uji normalitas saphiro wilk pada LDL kelompok perlakuan 3 (P3) pre-test yaitu 0,159 dan LDL kelompok perlakuan 3 (P3) post-test yaitu 0,501. Maka analisa data selanjutnya menggunakan uji Paired Sample T-Test. Pada uji Paired Sample T-Test diperoleh nilai mean $17,43 \mathrm{mg} / \mathrm{dl}$ pada LDL kelompok perlakuan 3 (P3) pre-test dan $5,43 \mathrm{mg} / \mathrm{dl}$ pada LDL kelompok perlakuan 3 (P3) post-test. Selanjutnya nilai sig. Pada uji Paired Sample T-Test diperoleh sebesar 0,018 $(p<0,05)$. Hal ini menunjukkan ada perbedaan yang signifikan kadar LDL kelompok kontrol pre dan post-test.

\section{PEMBAHASAN}

Berdasarkan penelitian yang telah dilakukan, diperoleh rata-rata kadar LDL setelah dan sesudah pemberian Minyak zaitun dan olahraga mampu menurunkan kadar LDL. Akan tetapi, pada penelitian ini ternyata tidak dijumpai peningkatan kadar kolesterol LDL pada tikus yang diinduksi kuning telur. Hal ini mungkin disebabkan karena dosis yang diberikan, lamanya waktu pemberian serta jenis pakan yang digunakan dan akan lebih baik jika menggunakan pakan telur puyuh karena kadar kolesterol pada telur puyuh sangat tinggi yaitu $844 \mathrm{mg} / \mathrm{dl}$ dibandingkan dengan kadar kolesterol pada telur ayam yang hanya memiliki kadar sebesar 423 mg/dl (9).

Setelah dilakukan uji hipotesis, didapatkan hasil pada kelompok perlakuaan P1 terdapat penurunan tidak bermakna yakni dengan nilai $\mathrm{p}=0,171$. Sehingga dapat diambil kesimpulan bahwa terdapat penurunan tidak bermakna pada kadar LDL kelompok perlakuan P1 tikus jantan galur wistar (Rattus novergicus L.) yang diberi diet tinggi lemak dengan intervensi minyak zaitun (Extra virgine olive oil) dan olahraga intensitas sedang.

Hasil penelitian ini berbeda dengan hasil penelitian sebelumnya yang menyatakan bahwa pemberian minyak zaitun ekstra virgin dengan dosis 0,9 gr/hari/ekor secara oral selama 21 hari menunjukkan adanya penurunan kadar kolesterol LDL yang signifikan (4). Penelitian 
sebelumnya juga menunjukkan hasil uji statistik dan diperoleh nilai $\mathrm{p}=0.002$ yang artinya adalah tidak sama atau berbeda signifikan sebelum dan sesudah perlakuan (10).

Selain itu hasil penelitian ini serupa dengan hasil penelitian sebelumnya, dimana penelitian dengan kelompok yang diberikan EVOO dan madu tidak memiliki perbedaan yang bermakna dengan nilai $p=0,927$ (11). Perbedaan antara hasil penelitian ini dengan penelitian sebelumnya mungkin dikarenakan oleh beberapa perbedaan yaitu dosis yang diberikan, lamanya waktu pemberian perlakuan dan komposisi isi minyak zaitun ekstra virgin yang digunakan.

Hasil uji statistik pada kelompok perlakuan 2 yang diberikan latihan olahraga intensitas sedang berupa berenang menunjukkan bahwa hubungannya bermakna yaitu sebesar $0,034(p<0,05)$. Hasil penelitian ini sejalan dengan penelitian sebelumnya yang menyatakan bahwa ada hubungan yang signifikan antara aktifitas fisik dengan kadar kolesterol darah total. Hal ini sejalan dengan teori, bahwa ketika melakukan aktivitas fisik, tubuh akan melakukan pembentukan energi yang berupa adenosin triphosphate (ATP) dari makanan yang dikonsumsi. Sehingga makanan yang dikonsumsi tidak banyak dibentuk menjadi kolesterol, akibatnya kadar kolesterol total di dalam tubuh menurun (12). Hasil penelitian ini juga selaras dengan penelitian sebelumnya yang menyatakan bahwa tingkat aktivitas fisik berpengaruh terhadap kadar kolesterol darah $(p<0,05)$ (13). Selain itu, juga dijelaskan bahwa aktivitas fisik memiliki hubungan yang signifikan dengan kadar kolesterol (14).

Hasil uji statistik pada kelompok perlakuan 3 yang diberikan kombinasi minyak zaitun dan latihan olahraga intensitas sedang berupa berenang menunjukkan bahwa hubungannya bermakna yaitu sebesar 0,018 $(p<0,05)$. Penurunan kadar LDL yang paling tinggi terdapat pada kelompok yang mendapat minyak zaitun dan olahraga intensitas sedang. Hasil penelitian sebelumnya menyatakan bahwa konsentrasi serum LDL bergantung pada laju produksi very low density lipoprptein (VLDL). Efek MUFA terhadap penurunan kadar LDL mungkin disebabkan karena berubahnya komposisi partikel VLDL yang kaya akan trigliserida dan bisa jadi dengan bertambahnya jumlah reseptor LDL atau berkurangnya konversi IDL menjadi LDL (4). Peningkatan pemberian MUFA menyebabkan berkurangnya konsentrasi apoB di dalam plasma sedangkan apo-B sendiri memberikan gambaran tentang jumlah partikel LDL yang beredar dalam darah, selain itu diet tinggi MUFA dan rendah asam lemak jenuh akan meningkatkan aktivitas reseptor LDL (15).

Hasil penelitian ini selaras dengan teori bahwa ketika melakukan olahraga, tubuh bergerak dan membantu membakar kalori yang ada sehingga menghasilkan energi yang dibutuhkan tubuh untuk bekerja dan mengurangi tertimbunnya lemak dalam tubuh. Olahraga yang teratur juga dapat membakar kolesterol LDL dan trigliserida serta meningkatkan kadar kolesterol baik (HDL). Hal ini sangat membantu tubuh tetap fit dan mengurangi resiko darah tinggi, stroke, kegemukan, dan penyakit jantung (16).

\section{KESIMPULAN}

Berdasarkan hasil penelitian dapat disimpulkan bahwa Olahraga dan kombinasi minyak zaitun dengan olahraga intensitas sedang berpengaruh dalam penurunan kadar LDL darah tikus jantan galur wistar (Rattus novergicus $L$ ) yang diberi diet tinggi lemak.

\section{UCAPAN TERIMAKASIH}

Dalam penyusunan artikel ini penulis mengucapkan terimakasih yang setulustulusnya kepada sahabat, saudara, rekan serta 
berbagai pihak yang tidak dapat saya sebutkan satu persatu.

\section{KONFLIK KEPENTINGAN}

Penulis tidak memiliki konflik kepentingan dan tidak ada afiliasi atau koneksi dengan atau dengan entitas atau organisasi apapun, yang dapat menimbulkan pertanyaan bias dalam diskusi dan kesimpulan naskah.

\section{REFERENSI}

1. Iqbal S, Adnan M, Khan RTM. Comparison Of Lipid Lowering Effect Of Extra Virgin Olive Oil and Atorvastatin in Dyslipidaemia in Type 2 Diabetes Melitus. Department of Pharmacology and Therapeutics Department of Community Medicine. J Ayub Med Coll Abbottabad. 2017;29(1):83-6.

2. WHO. Cardiovascular Disease (CVDs). World Heal Organ. 2017;

3. Menkes RI. Peraturan Menteri Kesehatan Republik Indonesia No.88 Tahun 2013 Tentang Rencana Induk Pengembangan Bahan Baku Obat Tradisional. 2013;

4. Nugraheni K. Pengaruh Pemberian Minyak Zaitun Ekstra Virgin Terhadap Profil Lipid Serum Tikus Putih (Rattus norvegicus) Strain Sprague Dawley Hiperkolesterolemia. Universitas Diponegoro; 2012.

5. Namayandeh SM, Kaseb F, Lesan S. Olive and sesame oil effect on lipid profile in hypercholesterolemic patients, which better? Int J Prev Med. 2013;4(9):1059-62.

6. Deforche B, Bourdeaudhuij I.D, Debode P, Vinaimont F, Hills A.P, Vertraete S BJ. Changes in fat mass, fat free mass and aerobic fitness in severely obesitas children and adolescents following arab residential treatment programme. Eur J Pediatr. 2013; 162: 616-22.

7. Palar C, Wongkar D, Ticoalu S. Manfaat Latihan Olahraga Aerobik Terhadap Kebugaran Fisik Manusia. J e-Biomedik. 2015;3(1).

8. Dahlan MS. Uji One Way Anova (Uji Hipotesis Komperatif Numerik Lebih dari Dua Kelompok Tidak Berpasangan Berdistribusi Normal). In: in: Statistik Untuk Kedokteran dan Kesehatan: Deskriptif, Bivariat, Dan MultivariatnDilengkapi Aplikasi Menggunakan SPSS. 2014.

9. Aviati V, Mardiati S., Saraswati T. Kadar Kolesterol Telur Puyuh Setelah Pemberian Tepung Kunyit Dalam Pakan. J Bul Anat dan Fisiol. 2014;112(1):58-64.

10. Rachmat Faisal Syamsu. Efek Pemberian Minyak Zaitun (Olive oil) Terhadap Perubahan Profil Lipid Pada Tikus Putih (Rattus novergicus). Fak Kedokteran, Univ Muslim Indones. 2017;9(1).

11. Suminar D, Kurniawaty E, Mustofa S. Pengaruh Protektif Pemberian Extra Virgin Olive Oil ( EVOO ) dan Madu Terhadap Kadar LDL Darah Tikus Putih Jantan Galur Sprague dawley yang Diinduksi Diet Tinggi Kolesterol. 2014;35-44.

12. Zuhroiyyah SF, Sukandar H, Sastradinanja SB. Hubungan Aktivitas Fisik dengan Kadar Kolesterol Total, Kolesterol LowDensity Lipoprotein, dan Kolesterol HighDensity Lipoprotein pada Masyarakat Jatinangor. J Sist Kesehat. 2017;2(3):116-22.

13. Waloya $\mathrm{T}$, Rimbawan $\mathrm{R}, \mathrm{N}$ A. Hubungan Antara Konsumsi Pangan dan Aktivitas Fisik dengan Kadar Kolesterol Darah Pria dan Wanita Dewasa di Bogor. J Gizi dan Pangan. 
2013;8(1):9-16.

14. Pilch WB, Mucha D, Palka T, Suder A, Piotrowska A, Tyka A, et al. The Influence of a 12-Week Program of Physical Activity on Changes in Body Composition and Lipid and Carbohydrate Status in Postmenopausal Women. Prz menopauzalny. 2015;14(4):231-7.

15. Perdido. Efek Pemberian Jus Avokad (Persea americana Mill.) Terhadap Kadar Kolesterol HDL dan LDL tikus putih (Rattus novergicus). Surakarta: Fakultas Kedokteran Universitas Sebelas Maret; 2011.

16. Landers D., S.M A. Exercise and Health Psychology. Phys Act Ment Heal. 2012;4671-491. 